\title{
ICTs and the Accounting Profession in a SIDS
}

\author{
Terry Harris ${ }^{1}$ \\ ${ }^{1}$ Lecturer, Management Studies, Faculty of Social Sciences, University of the West Indies, Cave Hill Campus, P.O. \\ Box 64, Barbados, W.I \\ Correspondence: Terry Harris, Lecturer, Management Studies, Faculty of Social Sciences, University of the West \\ Indies, Cave Hill Campus, P.O. Box 64, Barbados, W.I. E-mail: terry.harris@cavehill.uwi.edu
}

Received: June 29, 2014

Accepted: July 19, 2014

Online Published: July 21, 2014

doi:10.5430/afr.v3n3p58

URL: http://dx.doi.org/10.5430/afr.v3n3p58

\begin{abstract}
In this paper the author explores the usage and impacts of Information Communication Technology (ICT) on the accounting profession in Barbados, a Small Island Developing State (SIDS). The findings suggest that local accounting professionals have been slow in adopting advance ICT techniques with the top six usage of ICT being; writing letters, emailing and communicating, data entry, assisting in the reconciliation of bank statements, and production of financial statements and preparing working papers. Furthermore, the findings of a content analysis indicated that respondents perceived both positive and negative impacts of ICT.
\end{abstract}

Keywords: Information communication technology, Accounting profession, SIDS, Barbados

\section{Introduction}

Information Communication Technology (ICT) has rapidly changed the accounting profession over the last decades (Hunton, 2002). Accounting educators during this time have increased the number of topics including ICTs being taught to accounting students (Chang \& Hwang, 2003). This increase in ICT topics is attributed to an increased demand by public accounting firms for employees with this type of knowledge. In order to keep pace with a changing business environment (Elliott, 1995), public accountants have increased the number of services offered to clients such as online accounting and bookkeeping services, advisory services on selecting and implementing computerized accounting systems and accounting information data entry services. Accordingly, the advancement beyond the mere paper based recording, processing and reporting of economic activities (Banker, Chang and Kao, 2002), to an environment where ICTs now play a major role has provided opportunities and has posed new challenges for the accounting profession, which have occupied the attention of academics and researchers around the globe (Chang \& Hwang, 2003).

Furthermore, in the Small Island Developing State (SIDS) context, it is becoming increasingly important to quantify and qualify the impact and the usages of ICT in accounting profession. SIDS represent an important research environment as they have been noted to more slowly adopt advance technology (Harris, 2013a; 2013b). In Barbados and other SIDS, ICT have the potential to revolutionize the accounting profession (Elliott, 1995); particularly, in the areas of education, in the way accounting information is complied and reported by accountants, analyzed and scrutinized by auditors, understood and accessed by investors and the public (Jordan, 1999).

Accordingly, the purpose of this study is to identify the usages of ICT in the accounting profession in Barbados and evaluate the impact ICTs have had on the local profession. The rapid development of ICTs in accounting has provided opportunities and has posed new challenges for the accounting profession in more developed regions and this study considers an island economy heavily dependent on financial services. By providing some preliminary information on the impact and use of ICT in the accounting profession in Barbados, this study advances knowledge by identifying the peculiarities of accounting technology absorption and diffusion in the SIDS context. Furthermore, this paper highlights areas for improvement in the local accounting profession as the adoption of advanced ICTs have the potential to improve productive efficiencies. In addition, this study provides a framework to determine whether current ICT usage is at its optimal level given the technologies available, thereby enabling researchers to evaluate productivity and performances gains possible should full ICT usage be adopted.

\subsection{The Modern Accounting Profession a Historical Perspective}

Raghunandan (2002) defines the age old practice of accounting as the process that applies a set of concepts and 
techniques that collectively measure summarize record and report financial information about an entity, usually a business. According to them, accounting comprises three major aspects. Firstly, measuring and recording the result of operating, investing and financing activities of a business. Secondly, accounting entails summarizing total resources of the business and supplier of those resources. Finally, accounting includes the reporting of information about the financial performance and financial position of an entity in the form of periodic financial reports.

Traces of the accounting practice are said to be as old as civilization itself (Brown, 1968), while most historians confirmed that some form of the art was practiced in the accent Egyptian, Greek and Roman civilizations, these practices although comparable to modern day accounting theories do not give us the true origins of the modern accounting practice (Littleton \& Yamey, 1956).

Luca Pacioli (1445 - 1517) is credited with the birth of some modern accounting practices. His book Summa de arithmetica, geometrica, proportioni et proportionalita (Summa on arithmetic, geometry, proportions and proportionality in Venice), published in 1494, is heralded as the first accounting textbook. Luca Pacioli admitted that Summa is simple a compilation of materials and ideas from many sources and authors; he did not claim personal originality for the double-entry systems of bookkeeping. He states that he was in-fact merely writing down the system used by Venice merchants over two hundred years (Littleton \& Yamey, 1956). In Summa, Pacioli divided material into the following five topics; Arithmetic and algebra, its use in trade reckoning, Book-keeping, Money and exchange, and Pure and especially applied geometry. In them he continued to describe the use of journals and ledgers. His ledger had accounts for assets including receivables and inventories, liabilities, capital, income, and expenses he demonstrated year-end closing entries and proposed that a trial balance be used to prove a balanced ledger. He also touched on a wide range of related topics from accounting ethics to cost accounting (Littleton \& Yamey, 1956).

Paciolis' Summa formed the basis of books on double entry published in several other countries including England, Holland and France, over decades of publications on the subject and refinements of the techniques use the professional accountant began to emerge. In these early days, professional accountants were required to be well trained in recording, summarizing and reporting the economic activities of the firm. The economic activities of a business usually entailed many repetitive transitions; hence the accountant had to make a corresponding ledger adjustment manually. Modern times have brought the dawn of the age of ICT, which has been defined by Oxford Dictionary for the Business World (1993) as the process of handling, storing, retrieving, and distributing information. In this modern era, ICTs have been used in businesses to efficiently automate certain functions of several roles including the role of the accountant. Repetitive tasks such as the recording transactions, the tracking of accounts receivable and payable, the managing inventories, and payroll have all been replaced by the computer (Hunton, 2002). This evolution in business practice has caused the profession to change. The utilization and management of Accounting Information Systems (AIS) as well as other high order task now comprise the new role of the accounting professional (Hunton, 2002).

\subsection{The use of ICTs in the Accounting Profession}

As previously noted, the modern accounting profession is replete with examples of the usage of ICTs, ranging from its use in accounting practices and auditing processes. Accordingly, research into the uses of ICTs in accounting has been conducted and reported in academic papers and official reports emanating from accounting's governing and regulatory bodies. Furthermore, accounting educators and professional qualification providers have increased the usage of ICT in the education curriculum (Chang and Hwang, 2003). A model curriculum developed by International Standards of Accounting and Reporting (ISAR) suggests four (4) blocks of knowledge that comprise of organizational and business knowledge, accounting and accounting-related knowledge, general knowledge, and ICTs. The ICT component was detailed to include; ICT concepts for business systems, internal control in computer-based business systems, development standards and practices for business systems, the management of ICT adoption and implementation, and managing the security of information, artificial intelligence, expert systems, fuzzy logic and electronic commerce systems (Ricco, Saikata \& Gualberto, 2002). Profession destination providers such as the Association of Chartered Certified Accountants (ACCA) and Certified Public Accountant (CPA) have implemented ICTs in their curriculum in keeping with IEG11, which was issued by the Education Committee in 1995. According to the General IT Education Requirement in the pre-qualification level, to become a professional accountant a students must have at least general level knowledge of the ICT areas mentioned before, thereby ensuring that future accountants have a good working knowledge of the ICTs that have transformed their business environment (Elliott, 1995).

The new business environment for accountants includes the use of AIS integrated into enterprise resource planning (ERP) systems. This has caused the processes of recording and summarizing business and financial transactions to 
become almost completely automated. As these traditional roles of the accountant have been reliably given to computer systems and data entry personnel whom simply enter raw information into the computer system such data includes purchase invoices and sales receipt, the accountant adds little or no incremental value to organization in this capacity (Hunton, 2002). Accountants are now required to use management information systems (MIS) and other expert systems to aiding their decision making process and assist with planning at the strategic level. Thankfully, these systems provide great assistants to accountants in that they hold a wealth of knowledge on any issues and are designed to have artificial intelligence that can be used to tailor solutions to any given situation.

All told, computer systems are used by modern accountants to communicate, keep track of accounts payable and receivable, payroll, inventory, maintain financial control over assets, prepare and submit financial reports, analyses data, provide the current and estimated future values of the business to internal (managers, board of directors, CEO) and external (investors, bankers, suppliers, customers) users (Jordan, 1999). In addition, one recently developed advance accounting technology that enables continually and instantaneous reporting, is extensible business reporting language (XBRL) this technology increases the accuracy, efficiency, and transparency in financial reporting via the web. XBRL is a web language that is based on the more widely known extensible mark-up language (XML), but is specifically designed for financial reporting (Farewell\& Pinsker, 2005).

The use of ICTs in the assurance practice (audit) has also been noteworthy. Banker, Chang and Kao (2002) in a study of productivity of the Public accounting firms, looked that the usage of ICTs by auditing professionals starting with the junior auditor whose primary function is to perform assigned audit procedures and prepare working papers. The tasks entailed are mostly repetitive and involve substantial calculations and referencing across different accounts. It their study, the use of tailored auditing computer applications, in this case lotus notes a client-server, collaborative application can, automated such structured tasks and substantially reduces the processing time. Senior auditors and audit managers were also found to use ICTs in the development of audit plans, organization of audit activities, and supervision and review of the work of junior auditors

\subsection{The impact of ICTs in the Accounting Profession}

In accounting the impact and application of ICTs has been studied from different perspectives. Chang and Hwang (2003) found that entry-level auditors have had significantly more exposure to IT topics while in college than compared to more senior auditors, this implies that educators have modified there curricula by incorporating more ICT topics in to the program. The transition from a non ICT environment to an ICT based working environment for those practitioners whom have not been introduce to ICT at collage has not come as easy.

Lamberton, Fedorowicz and Roohani (2005) found that accountants with high Tolerance for Ambiguity (TOA) tended to accept the change towards computers more readily than accountants with low TOA levels; however, the recruiting practices in the profession have favored individuals with more conservative attitude towards risk for certain accounting and auditing positions and with good reason. Hence, the profession is dominated by individuals who are resistant to change toward more ICT usage. This research complements Chang and Hwang (2003) findings which showed that among 123 majors in Accounting and AIS degrees, that AIS majors showed higher tolerance for ambiguity an were more positive towards computers.

At the practitioner level the use of ICT has had an impact. The role of the accountant has been greatly changed from that of predominantly a bookkeeper. These task now reliably assign to the AIS, the worth of the accountant is now reflected in higher-order critical-thinking skills, such as designing business processes, providing professional financial ratio analysis on key business indicators, such as; activity, liquidity, profitability and dept vs. capital ratios and providing other consultation services (Hunton, 2002). At the firm level the impact on productivity ICT was researched by Banker, Chang and Kao (2002) in a studied of five offices of an international public accounting firm that recently made large if investments in ICTs, specifically in audit software and knowledge-sharing applications. The results from both indicate significant productivity gains following ICT implementation. This result correlates with Pinsonneault and Rivard (cited in Banker, Chang and Kao 2002) assertion that the productivity of accounting professionals is likely to improve due to ICT implementation since the primary responsibility of professionals in public accounting firms involves information intensive activities (Auditing Concepts Committee [ACC] 1972) including gathering, entering, organizing, processing, evaluating, and presenting data.

Hunton (2002) found that the services of public accountants have evolve and that the scope of assurance providing has been widen to include services which ascertain the reliability, integrity, and credibility of information systems, and electronic commerce systems. SysTrust and Webtrust are two relatively new services rolled-out by the American Institute of Certified Public Accountants (AICPA) and Canadian Institute of Chartered Accountants (CICA) to cover these two areas in the changing business environment. Lamberton, Fedorowicz and Roohani (2005) found that these 
changes have brought about higher levels of scrutiny around the accounting profession as investors and the public are more critical of the accounting profession and the information they produce.

More timely and accurate information provided by technological tools often cost the business accountability and confidentiality, leading to more opportunities for fraud to accrue (Jordan, 1999), from both internal and external sources as security and accessibility to databases and data streams becomes an important issue. AIS must therefore be design with the view to prevent fraud but where fraud prevention ends; forensic technology begins (Hydoski \& Hans, 2007). More forensic techniques are using ICTs to revile material misstatements intentional or otherwise which may accrue throughout AIS procedures and take preventative action. Increasing forensic accounting utilizes auditing and computer science in and investigating accounting information for legal purposes, there is a focus on software applications, data storage, data verification and validation (Hydoski \& Hans, 2007).

Given the uses of impacts of ICTs noted globally in more developed regions, the author of this paper seeks to identify the usages and impacts of ICTs in the Barbados and SIDS contexts. Consequently, the following research questions were formulated to guide the study:

RQ 1: What are the usages of ICT in the Accounting Profession in Barbados?

RQ 2: What are the impacts of ICT on the Accounting Profession in Barbados?

\section{Method}

\subsection{Introduction}

A quantitative survey was used to collect data to examine the usages and the impact ICTs are having within the accounting profession in Barbados. The quantitative survey approach is a commonly used research strategy by business researchers (Saunder, Lewis \& Thornhill, 2003). This method allows for easy comparisons and the appearance of authoritativeness (Saunders et al, 2003). A cross-sectional research design was adopted for this study. This research design allows the single time collection of data on several variables from a cross section of the population and can include large sample sizes (Babbie, 2004). The association between variables can also be tested for (Cerswell, 2003). One visible advantage of the cross sectional approach over other research methods is that the cross sectional research design is more cost effective and less time consuming (Creswell, 2003). A disadvantage of the method however is that cross sectional research design cannot provide a cause and effect test (Leedy and Ormorod, 2005). The survey methodology used to collect data in this study was in the form of self-report questionnaires.

The use of the survey method is a popular research strategy among researchers. The survey seeks to answer three main questions; why, how, who? (McDaniel et al, 2001). Aaker et al (1995) found that the main advantage of a survey is the ability to gather a lot of data about an individual respondent at one time. One more advantage of the method is versatility. Surveys can be deployed in any setting under most circumstances and is adaptable to research objectives, in either a descriptive or casual design. Attitudes are often the subjects of surveys, and it is through the attitude of the respondents that researchers are able to assess them and the extent to which the object been rated is either favorable or unfavorable in their view (Aaker et al, 1995).

The survey method does have its limitations. McDaniel et al (2001) highlighted some errors possible using survey research. These errors include; sampling errors which can be bias or result from a chance of variation, measurement errors which occurs when there is a discrepancy between the information sought and the information received, this poses a challenge to the accuracy of the results and finally systematic error which can result from the research design or execution. Aaker et al (1995) also identified some disadvantages stemming from the social interaction of the interviewer and the respondents. Ambiguities of questions, inaccuracy of responses, ambiguity of answers, non-responses are all examples of possible sources for errors.

The survey methodology use in this study was of the form of a self-report questionnaire. Self-report methodology surveys have the some limitations in that participant's responses in relation their attitudes and opinions may be biased by recent events or current context (Schwarz, 1999). Another limitation of the self-report methodology is that the questionnaire is subject to social desirable responding and impression management (Leedy \& Ormrond, 2005).

\subsection{Surveyed Population}

The questionnaires where hand delivered forty (40) to small and forty (40) to large firms, these firms comprised of public accounting firms, and businesses in various sectors, which employed the services of Chartered accountants and accounting staff. These firms were selected based on lists obtained from the Institute of Chartered Accountants, Barbados Statistical Department, and the Small Business Association of Barbados. For the purpose of this study, the 
Small Business Association of Barbados categorization of firms was adopted. Firms employing fewer than 25 employees were classified as small business and those employing more than 100 employees were considered large businesses. The author hoped to obtain at least 30 usable responses since Saunder et. al, (2003,p. 155) alluded to "The Economist" (1997) advice of a minimum number of 30 for statistical analyses provides a useful "rule of thumb" of the eighty (80) questionnaires distributed, forty five (45) usable questionnaires were obtained, a response rate of $56 \%$.

\subsection{Questionnaire Instrument}

The questionnaire was designed to examine the usages and impacts of ICTs in the accounting profession. The questionnaire covered the following areas: the personal demographic of the respondent which included, age, sex, qualifications, work experience and job type; the ways ICTs are used by the respondent in the execution of their duties; the type of software systems used by the respondents at work; the reliance and dependence of the respondent on ICTs; the attitude and opinion of the respondent towards ICT implementation. In addition, a qualitative question asking participants about their perceptions of the impact of ICTs on the accounting profession and how ICTs could be better utilized in the profession was included in the survey instrument.

\subsection{Analytical Techniques}

Descriptive statistics of usages and impacts of ICTs within the accounting profession were computed. In addition, Cross-tabulations and Chi-Square Statistics were computed to investigate likely relationships between the type of job or position held by the accounting professional and usages of ICTs. In addition, a content analysis was performed on the qualitative question to identify participant's perceptions of the impacts of ICTs on the accounting profession.

\section{Results and Analysis}

\subsection{Introduction}

This section presents the findings of statistical analyses computed for testing the two research questions of the current study. In advance of the testing of the research questions of this study, subscales were computed for each variable. Mean ratings were computed from the sores on these subscales and used for data analysis.

\subsection{ICT Usage}

The following subsections pertain to the first research question RQ 1: What are the usages of ICT in the Accounting Profession in Barbados?

\subsubsection{General Usages}

Table 1 reports percentages for usages of ICT measured in this study. The top six percentile general usages of ICTs found at all levels within the accounting professed in Barbados where; its use to help write letters $100 \%$, use in emailing and communicating $96.90 \%$, for data entry $84.40 \%$, assisting in the reconciliation of bank statements $78.10 \%$, use in producing of financial statements and preparing working papers both $65.6 \%$.

The high usage of ICTs in writing letters, communicating, preparing financial statements and reconciliation of bank accounts observed in this study, supports the findings of Jordan (1999) who identified communication, preparation of financial reports and maintaining financial controls as main areas where ICTs are revolutionizing the accounting profession. The popularity of digital data entry as a means of recording and storing information seen in the results of this project correlates well with a past study which indicated that data entry played a dominate role in the day to day recording of financial activity of a firm (Hunton, 2002). Moreover, the findings of this study, which indicated that a large percentage of the sample use ICTs for preparing working papers corroborate the findings of Banker, Chang and Kao (2002) study.

The five least general usages of ICTs found in this study were; its use in assisting in the decision making process of accounting professionals $9.40 \%$, Validation and verification of a company's website information $15.60 \%$, Reviewing the Work of Subordinates 34.4\% reviewing economic performance of companies 37.5\%, Preparing Financial Estimates 37.5\%, Testing Companies Accounting Information System 37.5\%, Tracking Inventory 37.5\%. These findings are somewhat contrary to those of Hunton (2002), who indicated that modern accounting professionals are increasingly dependent on ICT for making decisions and evaluating the web page information of clients and employers. However, Hunton (2002) did conclude that the use of ICTs for the verification and validation of web site is a relatively new. Accordingly, this result may be symptomatic of Barbados' underdeveloped state in this area. 
Table 1. Showing General ICT Usages

\begin{tabular}{lll}
\hline General ICT Usages & $\%$ Yes & $\%$ No \\
\hline Data Entry & & \\
Writing Letters & $84.40 \%$ & $15.60 \%$ \\
Emailing \& Communication & $100.00 \%$ & - \\
Preparing Payroll & $96.90 \%$ & $3.10 \%$ \\
Reconciling Bank Accounts & $46.90 \%$ & $53.10 \%$ \\
Making General Ledger Adjustments & $78.10 \%$ & $21.90 \%$ \\
Tracking Accounts Payable & $65.60 \%$ & $34.40 \%$ \\
Tracking Accounts Receivable & $59.40 \%$ & $40.60 \%$ \\
Tracking Inventory & $53.10 \%$ & $46.90 \%$ \\
Preparing Working Papers & $37.50 \%$ & $62.50 \%$ \\
Preparing Audit Plans & $65.60 \%$ & $34.40 \%$ \\
Testing Companies Accounting Information System & $50.00 \%$ & $50.00 \%$ \\
Verification and Validation of Database Information & $37.50 \%$ & $62.50 \%$ \\
Validation of Companies Website Information & $15.80 \%$ & $56.30 \%$ \\
Reviewing the Work of Subordinates & $34.40 \%$ & $64.40 \%$ \\
Producing Financial Statements & $65.60 \%$ & $34.40 \%$ \\
Preparing Budgets & $53.10 \%$ & $46.90 \%$ \\
Preparing Financial Estimates & $37.50 \%$ & $62.50 \%$ \\
Reviewing Economic Performance of Companies & $37.50 \%$ & $62.50 \%$ \\
Performing Ratio Analysis & $53.10 \%$ & $46.90 \%$ \\
Electronic reporting of Financial Information & $40.60 \%$ & $59.40 \%$ \\
Assist in Decision Making Process & $9.40 \%$ & $90.60 \%$ \\
\hline 3ications Used & & \\
\hline
\end{tabular}

\subsubsection{Software Applications Used}

The two most used software applications were word processors and digital spreadsheets $96.90 \%$, and the use of Accounting Information Systems (AIS) 75\% (table 2). These results were widely supported by the literature as both Jordan (1999) and Hunton (2002) found similar results in more developed economies. The two least used software applications were SysTrust and/or Webtrust $(9.4 \%)$ and XBRL $(0 \%)$. The low or nonexistent usage of the XBRL soft-ware application found in Barbados is at variance to the findings of past research conducted in more developed regions (Hunton, 2002). Moreover, this coupled with the low usage of SysTrust and/or Webtrust found in Barbados are consistent with the narrative that Barbados' accounting profession is lagging behind those of the technological leaders.

Table 2. Usage of Software Applications

\begin{tabular}{lll}
\hline Specific ICT Usages & $\%$ Yes & $\%$ No \\
\hline & & \\
Extensible Business Reporting Language (XBRL) & - & $100.00 \%$ \\
SysTrust and/ or Webtrust & $3.10 \%$ & $96.90 \%$ \\
Management Information Systems (MIS) & $9.40 \%$ & $90.60 \%$ \\
Accounting Information Systems (AIS) & $75.00 \%$ & $25.00 \%$ \\
Enterprise Resource Planning (ERP) & $53.10 \%$ & $46.90 \%$ \\
Word Processors and Spreadsheets & $96.90 \%$ & $3.10 \%$ \\
Tailored Auditing Software & $31.30 \%$ & $68.80 \%$ \\
\hline
\end{tabular}




\subsection{Chi-Square Statistical Analysis of Usage Pattern}

Cross-tabulations and Chi-square statistics were computed to investigate the likely relationship between type of job or position within the accounting profession and general ICT Usage (Table 3). The results indicated that there is a likely relationship between type of job or position within the accounting profession and the following ICT usages preparing payroll, testing companies accounting information system, verification and validation of the information on companies' websites, producing financial statements, verification and validation of database information, preparing financial estimates, reviewing economic performance of companies, performing ratio analysis, preparing budgets, and electronically reporting financial information.

\subsubsection{Significant Differences}

In terms of using ICTs for preparing payrolls, all financial controllers sampled indicated that they used ICTs for preparing payrolls, while $20 \%$ of accountants, $76.9 \%$ of accounting clerks, $0 \%$ of auditing managers, all senior auditors, and $0 \%$ of junior auditors indicated that they used ICTs for preparing payrolls. Chi-square statistics indicated that there is a likely relationship between type of job or position within the accounting profession and usage of ICTs for preparing payroll $\left(X^{2}=19.520, \mathrm{p}<.05\right)$. This indicates that financial controllers, accounting clerks, and senior auditors are more likely to used ICTs for preparing payrolls than auditing managers and junior auditors.

In relation to using ICTs for testing companies Accounting Information Systems (AIS), all financial controllers sampled indicated that they used ICTs for testing AIS, while $20 \%$ of accountants, $0 \%$ of accounting clerks, $50 \%$ of auditing managers, all senior auditors, and $75 \%$ of junior auditors indicated that they used ICTs testing AIS. Chi-square statistics indicated that there is a likely relationship between type of job or position within the accounting profession and usage of ICTs for testing AIS $\left(X^{2}=20.053, \mathrm{p}<.05\right)$. This indicates that financial controllers, audit managers, senior auditors and junior auditors are more likely to used ICTs for testing companies accounting information system than accountants and accounting clerks.

Concerning the use of ICTs for verification and validation of companies' website information, $50 \%$ of financial controllers sampled indicated that they used ICTs for verification and validation of information on websites, while $0 \%$ of accountants, $0 \%$ of accounting clerks, $50 \%$ of auditing managers, all senior auditors, and $12.5 \%$ of junior auditors indicated that they used ICTs testing website information. Chi-square statistics indicated that there is a likely relationship between type of job or position within the accounting profession and usage of ICTs for verification and validation of website information $\left(X^{2}=17.778, \mathrm{p}<.05\right)$. This indicates that financial controllers, audit managers, and senior auditors are more likely to used ICTs for verification and validation of information on company websites than accountants, accounting clerks and junior auditors. This finding correlates with a past study by Hunton (2002).

Referring to the use of ICTs for producing financial statements, all financial controllers sampled indicated that they used ICTs to produce financial statements, while $80 \%$ of accountants, $30.8 \%$ of accounting clerks, all auditing managers, all senior auditors, and $87.5 \%$ of junior auditors indicated that they used ICTs for preparing payrolls. Chi-square statistics indicated that there is a likely relationship between type of job or position within the accounting profession and usage of ICTs for producing statements $\left(X^{2}=12.299, \mathrm{p}<.05\right)$. This indicates that financial controllers, accountants, senior auditors and junior auditors are more likely to used ICTs for producing financial statements than accounts clerks. This finding supports the results of prior work conducted in this area by Hunton, (2002) and Jordan (1999).

Regarding of using ICTs for verification and validation of database information, all financial controllers sampled indicated that they used ICTs to verify and validate database information, while $0 \%$ of accountants, $38.5 \%$ of accounting clerks, $0 \%$ of auditing managers, all senior auditors, and $62.5 \%$ of junior auditors indicated that they used ICTs to verify and validate database information. Chi-square statistics indicated that there is a likely relationship between type of job or position within the accounting profession and usage of ICTs to verify and validate database information $\left(X^{2}=11.878, \mathrm{p}<.05\right)$. This indicates that financial controllers, senior auditors and junior auditors are more likely to used ICTs to verify and validate database information than accountants, accounting clerks and auditing managers and gives some support to the study of Hydoski and Hans (2007) who found similar results.

As it relates to the use of ICTs for testing companies preparing financial estimates, all financial controllers sampled indicated that they used ICTs to prepare financial estimates, while $20 \%$ of accountants, $0 \%$ of accounting clerks, $50 \%$ of auditing managers, all senior auditors, and $75 \%$ of junior auditors indicated that they used ICTs to prepare financial estimates. Chi-square statistics indicated that there is a likely relationship between type of job or position within the accounting profession and usage of ICTs to prepare financial estimates $\left(X^{2}=20.053, \mathrm{p}<.05\right)$. This indicates that financial controllers, audit managers, senior auditors and junior auditors are more likely to used ICTs to 
prepare financial estimates than accountants and accounting clerks.

Furthermore, regarding the use of ICTs for reviewing economic performance of companies, all financial controllers sampled indicated that they used ICTs for preparing payrolls, while $40 \%$ of accountants, $0 \%$ of accounting clerks, $50 \%$ of auditing managers, all senior auditors, and $62.5 \%$ of junior auditors indicated that they used ICTs to review economic performance of companies. Chi-square statistics indicated that there is a likely relationship between type of job or position within the accounting profession and usage of ICTs to review economic performance of companies $\left(X^{2}=16.747, \mathrm{p}<.05\right)$. This indicates that financial controllers, audit managers, senior auditors and junior auditors are more likely to used ICTs for preparing payrolls than accountants and accounts clerks. This supports the previous research of Banker, Chang and Koa (2002).

As it concerns the use of ICTs for perform ratio analysis, all financial controllers sampled indicated that they used ICTs to produce financial statements, while $20 \%$ of accountants, $23.1 \%$ of accounting clerks, all auditing managers, all senior auditors, and $87.5 \%$ of junior auditors indicated that they used ICTs to perform ratio analysis. Chi-square statistics indicated that there is a likely relationship between type of job or position within the accounting profession and usage of ICTs for producing statements $\left(X^{2}=16.007, \mathrm{p}<.05\right)$. This indicates that financial controllers, audit managers, senior auditors and junior auditors in Barbados are more likely to used ICTs to perform ratio analysis than accountants and accounts clerks. This finding is consistent with the previous research conducted by Jordan, (1999).

In addition, in relation to the use of ICTs for preparing budgets, all financial controllers sampled indicated that they used ICTs to prepare budgets, while $40 \%$ of accountants, $23.1 \%$ of accounting clerks, all audit managers, all senior auditors, and $75 \%$ of junior auditors indicated that they used ICTs to prepare budgets. Chi-square statistics indicated that there is a likely relationship between type of job or position within the accounting profession and usage of ICTs to prepare budgets $\left(X^{2}=11.891, \mathrm{p}<.05\right)$. This indicates that financial controllers, audit managers, senior auditors and junior auditors are more likely to used ICTs to prepare financial estimates than accountants and accounting clerks.

Moreover, in terms of the use of ICTs to electronically report financial information, all financial controllers sampled indicated that they used ICTs to electronically report financial information, while $40 \%$ of accountants, $0 \%$ of accounting clerks, $0 \%$ of auditing managers, all senior auditors, and $87.5 \%$ of junior auditors indicated that they used ICTs to electronically report financial information. Chi-square statistics indicated that there is a likely relationship between type of job or position within the accounting profession and usage of ICTs to electronically report financial information $\left(X^{2}=23.398, \mathrm{p}<.05\right)$. This indicates that financial controllers, senior auditors and junior auditors are more likely to used ICTs for preparing payrolls than accountants, accounts clerks and audit managers and this finding supports the previous research (Jordan, 1999).

The other results of Chi-square statistics did not indicate a likely relationship between type of job or position within the accounting profession and the following ICT usages-data entry, Emailing and communicating, Reconciling Bank Accounts, Making General ledger, Tracking Accounts Payable, Tracking Accounts Receivable, Tracking Inventory, Preparing Working Paper, Preparing Audit Plans, Reviewing Work of Subordinates, Assist in the decision Making Process- (all ps >.05).

Table 3. Showing relationship between type of job or position and general ICT Usage

\begin{tabular}{|c|c|c|c|c|c|c|c|c|c|}
\hline \multicolumn{4}{|c|}{ Producing Financial Statements } & & \multicolumn{5}{|c|}{ Testing Companies Accounting Information System } \\
\hline & Yes & No & $\mathrm{X}^{2}$ & $\mathrm{p}$ & & Yes & No & $\mathrm{X}^{2}$ & $\mathrm{p}$ \\
\hline Financial Controller & $100.00 \%$ & - & 12.299 & 0.031 & Financial Controller & $100.00 \%$ & - & 20.053 & 0.001 \\
\hline Accountant & $80.00 \%$ & $20.00 \%$ & & & Accountant & $20.00 \%$ & $80.00 \%$ & & \\
\hline Accounts Clerk & $30.80 \%$ & $69.20 \%$ & & & Accounts Clerk & - & $100.00 \%$ & & \\
\hline Audit Manager & $100.00 \%$ & - & & & Audit Manager & $50.00 \%$ & $50.00 \%$ & & \\
\hline Senior Auditor & $100.00 \%$ & - & & & Senior Auditor & $100.00 \%$ & - & & \\
\hline Junior Auditor & $87.50 \%$ & $12.50 \%$ & & & Junior Auditor & $75.00 \%$ & $25.00 \%$ & & \\
\hline \multirow[t]{2}{*}{ Preparing Budgets } & & & & \multicolumn{6}{|c|}{ Verification \& Validation of Database Information } \\
\hline & Yes & No & $x^{2}$ & & & Yes & No & $\mathrm{X}^{2}$ & $\mathrm{p}$ \\
\hline Financial Controller & $\begin{array}{c}\text { res } \\
100.00 \%\end{array}$ & No & $\begin{array}{c}x^{-} \\
11891\end{array}$ & $\begin{array}{c}\mathrm{p} \\
0036\end{array}$ & Financial Controller & $100.00 \%$ & - & 11.878 & 0.036 \\
\hline Accountant & $40.00 \%$ & $6000 \%$ & & & Accountant & - & $100.00 \%$ & & \\
\hline Accounts Clerk & $23.10 \%$ & $76.90 \%$ & & & Accounts Clerk & $38.50 \%$ & $61.50 \%$ & & \\
\hline Audit Manager & $10000 \%$ & 70.9070 & & & Audit Manager & - & $100.00 \%$ & & \\
\hline Senior Auditor & $10000 \%$ & 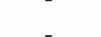 & & & Senior Auditor & $100.00 \%$ & - & & \\
\hline Junior Auditor & $75.00 \%$ & $25.00 \%$ & & & Junior Auditor & $62.50 \%$ & $37.50 \%$ & & \\
\hline
\end{tabular}




\begin{tabular}{|c|c|c|c|c|c|c|c|c|c|}
\hline \multicolumn{5}{|c|}{ Preparing Financial Estimates } & \multicolumn{5}{|c|}{ Verification \& Validation of Companies Website } \\
\hline & Yes & No & $\mathrm{X}^{2}$ & $\mathrm{p}$ & & Yes & No & $X^{2}$ & $\mathrm{p}$ \\
\hline Financial Controller & $100.00 \%$ & - & 20.053 & 0.001 & Financial Controller & $50.00 \%$ & $50.00 \%$ & 17.778 & 0.003 \\
\hline Accountant & $20.00 \%$ & $80.00 \%$ & & & Accountant & - & $100.00 \%$ & & \\
\hline Accounts Clerk & - & $100.00 \%$ & & & Accounts Clerk & - & $100.00 \%$ & & \\
\hline Audit Manager & $50.00 \%$ & $50.00 \%$ & & & Audit Manager & $50.00 \%$ & $50.00 \%$ & & \\
\hline Senior Auditor & $100.00 \%$ & - & & & Senior Auditor & $100.00 \%$ & - & & \\
\hline Junior Auditor & $75.00 \%$ & $25.00 \%$ & & & Junior Auditor & $12.50 \%$ & $87.50 \%$ & & \\
\hline
\end{tabular}

Reviewing Economic Performance of Companies

$\begin{array}{lcccc} & \text { Yes } & \text { No } & \mathrm{X}^{2} & \mathrm{p} \\ \text { Financial Controller } & 100.00 \% & - & 16.747 & 0.005 \\ \text { Accountant } & 40.00 \% & 60.00 \% & & \\ \text { Accounts Clerk } & - & 100.00 \% & & \\ \text { Audit Manager } & 50.00 \% & 50.00 \% & & \\ \text { Senior Auditor } & 100.00 \% & - & & \\ \text { Junior Auditor } & 62.50 \% & 37.50 \% & & \end{array}$

Electronically Reporting Financial Information

$\begin{array}{lcccc} & \text { Yes } & \text { No } & \mathrm{X}^{2} & \mathrm{p} \\ \text { Financial Controller } & 100.00 \% & - & 23.398 & 0.000 \\ \text { Accountant } & 40.00 \% & 60.00 \% & & \\ \text { Accounts Clerk } & - & 100.00 \% & & \\ \text { Audit Manager } & - & 100.00 \% & & \\ \text { Senior Auditor } & 100.00 \% & - & & \\ \text { Junior Auditor } & 87.50 \% & 12.50 \% & & \end{array}$

Data Entry

Performing Ratio Analysis

$\begin{array}{lcccc} & \text { Yes } & \text { No } & \mathrm{X}^{2} & \mathrm{p} \\ \text { Financial Controller } & 100.00 \% & - & 16.007 & 0.007 \\ \text { Accountant } & 20.00 \% & 80.00 \% & & \\ \text { Accounts Clerk } & 23.10 \% & 76.90 \% & & \\ \text { Audit Manager } & 100.00 \% & - & & \\ \text { Senior Auditor } & 100.00 \% & - & & \\ \text { Junior Auditor } & 87.50 \% & 12.50 \% & & \end{array}$

Tracking Inventory

$\begin{array}{lcccc} & \text { Yes } & \text { No } & \mathrm{X}^{2} & \mathrm{p} \\ \text { Financial Controller } & 100.00 \% & - & 14.515 & 0.013 \\ \text { Accountant } & 20.00 \% & 80.00 \% & & \\ \text { Accounts Clerk } & 7.70 \% & 92.30 \% & & \\ \text { Audit Manager } & 50.00 \% & 50.00 \% & & \\ \text { Senior Auditor } & 100.00 \% & - & & \\ \text { Junior Auditor } & 62.50 \% & 37.50 \% & & \end{array}$

Preparing Working Paper

$\begin{array}{lcccc} & \text { Yes } & \text { No } & \mathrm{X}^{2} & \mathrm{p} \\ \text { Financial Controller } & 100.00 \% & - & 6.264 & 0.281 \\ \text { Accountant } & 60.00 \% & 40.00 \% & & \\ \text { Accounts Clerk } & 46.20 \% & 53.80 \% & & \\ \text { Audit Manager } & 50.00 \% & 50.00 \% & & \\ \text { Senior Auditor } & 100.00 \% & - & & \\ \text { Junior Auditor } & 87.50 \% & 12.50 \% & & \\ & & & \end{array}$

$\begin{array}{lcccc} & \text { Yes } & \text { No } & \mathrm{X}^{2} & \mathrm{p} \\ \text { Financial Controller } & 100.00 \% & - & 10.761 & 0.560 \\ \text { Accountant } & 80.00 \% & 20.00 \% & & \\ \text { Accounts Clerk } & 100.00 \% & - & & \\ \text { Audit Manager } & 100.00 \% & - & & \\ \text { Senior Auditor } & 100.00 \% & - & & \\ \text { Junior Auditor } & 50.00 \% & 50.00 \% & & \end{array}$

Emailing and communicating

$\begin{array}{lcccc} & \text { Yes } & \text { No } & \mathrm{X}^{2} & \mathrm{p} \\ \text { Financial Controller } & 100.00 \% & - & 1.509 & 0.912 \\ \text { Accountant } & 100.00 \% & - & & \\ \text { Accounts Clerk } & 92.30 \% & 7.70 \% & & \\ \text { Audit Manager } & 100.00 \% & - & & \\ \text { Senior Auditor } & 100.00 \% & - & & \\ \text { Junior Auditor } & 100.00 \% & - & & \end{array}$

Reconciling Bank Accounts

\begin{tabular}{lcccc} 
& Yes & No & $\mathrm{X}^{2}$ & $\mathrm{p}$ \\
Financial Controller & $100.00 \%$ & - & 10.946 & 0.052 \\
Accountant & $80.00 \%$ & $20.00 \%$ & & \\
Accounts Clerk & $92.30 \%$ & $7.70 \%$ & & \\
Audit Manager & $100.00 \%$ & - & & \\
Senior Auditor & $100.00 \%$ & - & & \\
Junior Auditor & $62.50 \%$ & $37.50 \%$ & & \\
\hline
\end{tabular}


Preparing Audit Plans

$\begin{array}{lcccc} & \text { Yes } & \text { No } & \mathrm{X}^{2} & \mathrm{p} \\ \text { Financial Controller } & 50.00 \% & 50.00 \% & 6.623 & 0.250 \\ \text { Accountant } & 40.00 \% & 60.00 \% & & \\ \text { Accounts Clerk } & 30.80 \% & 69.20 \% & & \\ \text { Audit Manager } & 100.00 \% & - & & \\ \text { Senior Auditor } & 100.00 \% & - & & \\ \text { Junior Auditor } & 62.50 \% & 37.50 \% & & \end{array}$

Making General ledger

$\begin{array}{lcccc} & \text { Yes } & \text { No } & \mathrm{X}^{2} & \mathrm{p} \\ \text { Financial Controller } & 100.00 \% & - & 10.049 & 0.074 \\ \text { Accountant } & 100.00 \% & - & & \\ \text { Accounts Clerk } & 38.50 \% & 61.50 \% & & \\ \text { Audit Manager } & 100.00 \% & - & & \\ \text { Senior Auditor } & 100.00 \% & - & & \\ \text { Junior Auditor } & 62.50 \% & 37.50 \% & & \end{array}$

Reviewing Work of Subordinates

\begin{tabular}{lcccc} 
& Yes & No & $\mathrm{X}^{2}$ & $\mathrm{p}$ \\
Financial Controller & $50.00 \%$ & $50.00 \%$ & 5.539 & 0.354 \\
Accountant & $40.00 \%$ & $60.00 \%$ & & \\
Accounts Clerk & $30.80 \%$ & $69.20 \%$ & & \\
Audit Manager & $100.00 \%$ & - & & \\
Senior Auditor & - & $100.00 \%$ & & \\
Junior Auditor & $25.00 \%$ & $75.00 \%$ & & \\
\hline
\end{tabular}

Tracking Accounts Payable

$\begin{array}{lcccc} & \text { Yes } & \text { No } & \mathrm{X}^{2} & \mathrm{p} \\ \text { Financial Controller } & 100.00 \% & - & 3.785 & 0.581 \\ \text { Accountant } & 60.00 \% & 40.00 \% & & \\ \text { Accounts Clerk } & 46.20 \% & 53.80 \% & & \\ \text { Audit Manager } & 50.00 \% & 50.00 \% & & \\ \text { Senior Auditor } & 100.00 \% & - & & \\ \text { Junior Auditor } & 62.50 \% & 37.50 \% & & \end{array}$

Assist in the decision Making Process

$\begin{array}{lcccc} & \text { Yes } & \text { No } & \mathrm{X}^{2} & \mathrm{p} \\ \text { Financial Controller } & 50.00 \% & 50.00 \% & 6.400 & 0.269 \\ \text { Accountant } & 20.00 \% & 80.00 \% & & \\ \text { Accounts Clerk } & - & 100.00 \% & & \\ \text { Audit Manager } & - & 100.00 \% & & \\ \text { Senior Auditor } & - & 100.00 \% & \\ \text { Junior Auditor } & 12.50 \% & 87.50 \% & \end{array}$

Writing Letters

$\begin{array}{lcccc} & \text { Yes } & \text { No } & \mathrm{X}^{2} & \mathrm{p} \\ \text { Financial Controller } & 100.00 \% & - & \mathrm{b} & - \\ \text { Accountant } & 100.00 \% & - & & \\ \text { Accounts Clerk } & 100.00 \% & - & & \\ \text { Audit Manager } & 100.00 \% & - & \\ \text { Senior Auditor } & 100.00 \% & - & \\ \text { Junior Auditor } & 100.00 \% & - & \end{array}$

Tracking Accounts Receivable

$\begin{array}{lcccc} & \text { Yes } & \text { No } & \mathrm{X}^{2} & \mathrm{p} \\ \text { Financial Controller } & 100.00 \% & - & 6.524 & 0.259 \\ \text { Accountant } & 60.00 \% & 40.00 \% & & \\ \text { Accounts Clerk } & 30.80 \% & 69.20 \% & & \\ \text { Audit Manager } & 50.00 \% & 50.00 \% & & \\ \text { Senior Auditor } & 100.00 \% & - & & \\ \text { Junior Auditor } & 62.50 \% & 37.50 \% & & \end{array}$

Preparing Payroll

$\begin{array}{lllll} & \text { Yes } & \text { No } & \mathrm{X}^{2} & \mathrm{p} \\ \text { Financial Controller } & 100.00 \% & - & 19.520 & 0.002 \\ \text { Accountant } & 20.00 \% & 80.00 \% & & \\ \text { Accounts Clerk } & 76.90 \% & 23.10 \% & & \\ \text { Audit Manager } & - & 100.00 \% & & \\ \text { Senior Auditor } & 100.00 \% & - & & \\ \text { Junior Auditor } & - & 100.00 \% & & \end{array}$

\subsection{Impact of ICTs}

Next the author explore research question RQ 2 with asks "What are the impacts of ICT on the Accounting Profession in Barbados?" Accordingly this subsection presents the results of further analysis which sought to elicit the perceptions and opinions of Barbados based accountants concerning the impacts ICTs are having.

\subsubsection{Content Analysis}

A content analysis was conducted of a qualitative question, which asks respondents for their opinion in relation to the impact of ICTs on the Accounting Profession in Barbados. The findings of the content analysis are reported in Table 4 where two broad categories of impacts of ICTs emerged from the analysis-positive and negative impacts. Positive impacts highlighted by the respondents were global connectivity, greater and easier access to information, rapid communication, improved competitiveness, enhanced quality of work, faster work process, productivity, and enhance business practices. In addition, enhanced the quality of work and faster work process were the most salient positive impacts. The negative impacts that emerged were constant need of training and constant need of investment. 
Table 4. Categories and percentages of impact stated by respondents

\begin{tabular}{lll}
\hline Category of Impacts & $\%$ of Respondents \\
\hline Positive & & \\
& Global connectivity & $11.10 \%$ \\
& Greater and easier access to information & $22.20 \%$ \\
& Rapid communication & $22.20 \%$ \\
& Improved Competitiveness & $22.20 \%$ \\
& Enhanced Quality of work & $77.30 \%$ \\
& Faster work process & $77.30 \%$ \\
& Productivity & $23.10 \%$ \\
& Enhance business practices & $23.10 \%$ \\
Negative & & \\
& & \\
& Constant need of training & $13.60 \%$ \\
\hline
\end{tabular}

\subsubsection{Descriptive Statistics Analysis}

Descriptive statistics were computed for questions, which assessed impacts of ICTs (Table 5). Mean scores of 4 and greater indicated strong agreement with statement, while mean scores of 3 and greater but less than 4 indicated moderate agreement with statements, and mean scores of less than 3 indicted disagreements with statements.

The respondents strongly agreed that advancements in ICTs have made their job easier and more efficient, and that accountants in order to survive in the accounting profession as a result of ICTs should be skilled in designing business processes and providing financial ratio analysis. This supports the findings of previous studies (Elliott, 1995; Jordan, 1999).

Respondents moderately agreed that ICT usage has improved efficiency, and as a result of ICTs, accountants do not perform traditional roles such as bookkeeping. Moreover, respondents moderately agreed that ICTs have increase productivity within the accounting profession. In addition, respondents moderately agreed that ICTs have lead to public accountants providing a greater level of assurance and have allowed the accounting profession to be more transparent and accountable. These findings were similar to that found by past research (Chang \& Hwaug, 2003; Hunton, 2002; Jordan, 1999) and corroborated the results of Lamberton, Fedorowicz and Roohani (2005).

Table 5. Descriptive Statistics for ICT Impact Items

\begin{tabular}{|c|c|c|c|}
\hline Statements & $\mathrm{N}$ & M & SD \\
\hline Advancements in ICTs have made my job easier and more efficient. & 32 & 4.06 & 0.759 \\
\hline I feel threaten by greater presence of technology in the work place. & 32 & 1.87 & 0.871 \\
\hline I have identified areas in which ICT usage would improve efficiency. & 32 & 3.63 & 0.976 \\
\hline $\begin{array}{l}\text { As a result of ICTs Accountants do not manually perform traditional roles such as } \\
\text { bookkeeping. }\end{array}$ & 32 & 3.31 & 1.070 \\
\hline $\begin{array}{l}\text { Accountants in order to survive in the accounting profession as a result of ICTs should } \\
\text { be skilled in designing business processes and providing financial ratio analysis }\end{array}$ & 32 & 4.00 & 0.984 \\
\hline Productivity in the accounting profession has improved due to ICT implementation. & 32 & 3.84 & 0.677 \\
\hline $\begin{array}{l}\text { ICTs advancements have lead to public accountants providing a greater level of } \\
\text { assurance. }\end{array}$ & 32 & 3.38 & 0.942 \\
\hline ICTs have allowed the accounting profession to be more transparent and accountable. & 32 & 3.06 & 1.105 \\
\hline $\begin{array}{l}\text { With the growing utilization of ICTs do you believe that the role of the accounting has } \\
\text { been diminished? }\end{array}$ & 32 & 2.06 & 0.840 \\
\hline $\begin{array}{l}\text { In order to effectively perform my job I have to be up to date with the ICT changes } \\
\text { within the profession. }\end{array}$ & 32 & 3.81 & 0.965 \\
\hline Advancements in ICTs have lead to profession being consistently retained. & 32 & 3.69 & 0.859 \\
\hline Public scrutiny levels have increased due to ICT advancements. & 32 & 3.63 & 0.871 \\
\hline
\end{tabular}




\section{Conclusion}

ICTs are revolutionizing the business of accounting, extant literature on ICTs in the accounting profession has found evidence of ICT impacts and examples of its usages. The results of the current study generally support the research of previous studies; however, evidence of some lag in terms of the use of more advance accounting technologies such as SysTrust, Webtrust, and XBRL was also noted. Nevertheless, the current findings suggest that there are many positive impacts if ICTs on the Barbados accounting profession. And these include enhancing the quality of work produce by professionals and to make the overall work process faster, thereby improving efficiency and effectiveness of accounting professionals. These results are constant with past research (Hunton, 2002; Jordan 1999). In addition, other positive impacts of ICTs found in the current study include its ability to enhance the global connectivity of the professional, provide greater and easier access by accounting professional to information, enable rapid communication enhance local business practices, and improved competitiveness and productivity.

The current study also found evidence of the negative impacts ICTs are having. The constant need to train and re-train professions and the continual need for financial investment are two of the negative impacts of ICTs found in this study and are supported in literature (Hunton, 2002; Banker, Chang and Kao, 2002). These negative impacts points to the investment by the profession of two of its most valued resources time and money. This investment of the accounting profession and professionals in themselves is a necessary cost in order for the profession to remain relevant in a changing business environment (Elliott, 1995).

All told, the main uses of ICTs in Barbados found in the current study were; its use in data entry, writing letters, emailing and communication, reconciling bank accounts, making general ledger adjustments, and producing financial statements. These main uses of ICTs generally support the finding of past studies (Hunton, 2002; Jordan; 1999; Banker, Chang and Kao, 2002). The current study also found local variance with the practice in more developed communities, consistent with Barbados representing an interesting case in the SIDS space. In addition to the limited use of SysTrust, Webtrust, and XBRL that has been previously noted, the current study found restricted use of ICTs to assist in the decision making process by local accounting professionals.

\subsection{Suggestions for Future Research}

In light of the contribution made to literature by the current study, further research is needed to determine the level of ICT usage and its impact on the accounting profession and the productivity of accountants. For example, future research might consider the impact of ICTs on the productivity of accountants, practices of accountants, ethical behavior and accounting reporting.

Moreover, because of the relative small size of the current study, a future study of the same nature with a larger sample should be replicated. Furthermore, a future study that produces similar findings would add validity to results of the current study.

\section{References}

Aaker,D. Kumar, V. Day, G. (1995). Marketing Research. New York, NY: John Wiley and Sons.

ACC. (1972). Report of the committee on basic auditing concepts. The accounting review, 47, (42), 18.

Babbie, E. (2004). The Practice of Social Research (10th ed.). Wadsworth, OH: Thomson.

Banker, R. Chang, H. Kao, Y. (2002). Impact of information technology on public accounting firm productivity, Journal of Information Systems, 16(2), 209-222. http://dx.doi.org/10.2308/jis.2002.16.2.227

Brown, R. (1968). A History of Accounting and Accountants (1st ed.). London, UK: Routledge.

Cerswell, J. (2003). Research Design: Qualitative, Quantitative, and Mixed Methods (2nd ed.). Thousand Oaks, CA: Sage Publications.

Chang, C. Hwang, N. (2003). Accounting education, firm training and information technology, Journal of Accounting Education, 12 (4), 441-450. http://dx.doi.org/10.1080/0963928032000065557

Elliott, K. (1995). The future of assurance services: Implications for academia. Accounting Horizons, 9, 118-127.

Farewell, S. Pinsker, R. (2005). XBRL and Financial Information Assurance Services, The CPA Journal, 75, (5), 2-3.

Harris, T. (2013a). Default definition selection for credit scoring. Artificial Intelligence Research, 2(4), 49.

Harris, T. (2013b). Quantitative credit risk assessment using support vector machines: Broad versus Narrow default definitions. Expert Systems with Applications, 40(11), 4404-4413. http://dx.doi.org/10.1016/j.eswa.2013.01.044

Hunton, J. (2002). Blending information and communication technology with accounting research, Accounting 
Horizons, 16, 55. http://dx.doi.org/10.2308/acch.2002.16.1.55

Hydoski, F. Hans, S. (2007). Where Fraud Prevention Ends, Forensic Technology Begins. Retrieved November 4, 2013, from: http://www.highbeam.com/doc/1P3-1325372451.html.

Jordan, A. (1999). The impact technology is having on the accounting profession, Journal of Accounting Education, 17, 341. http://dx.doi.org/10.1016/S0748-5751(99)00009-3

Lamberton, B. Fedorowicz, J. Roohani, S. (2005). Tolerance for Ambiguity and IT Competency among Accountants, Journal of Information Systems, 19, 75-95. http://dx.doi.org/10.2308/jis.2005.19.1.75

Leedy, P. Ormrod, J. (2005). Practical Research: Planning and Design (8th ed.). Upper Saddle River, NJ: Pearson Prentice Hall.

Littleton, A. and Yamey, B. (1956). Studies in the History of Accounting. London, UK: Sweet \& Maxwell.

McDaniel, M.A., Morgeson, F.P., Finnegan, E.B., Campion, M.A., \& Braverman, E.P. (2001). Use of situational judgment tests to predict job performance: A clarification of the literature. Journal of Applied Psychology, 86, 730-740. http://dx.doi.org/10.1037/0021-9010.86.4.730

Oxford Dictionaries. (1993). Oxford Dictionary for the Business World. New York, NY: Oxford University Press.

Raghunandan, M. (2002). Introduction to Financial Accounting. Fulton, CA: The Authors Publishing.

Ricco, E. Saikata, M. Gualberto, L. (2002). Information systems and technology in accounting, Retrieved November 7, 2013, from: http://www.fdewb.unimaas.nl/marc/ecais_new/files/riccio.pdf.

Saunder, M. Lewis, P. Thornhill, A. (2003). Research Methods for Business Students (3 ed). Harlow, UK: Pearson.

Schwarz, N. (1999). Self-reports: how the questions shape the answers. American psychologist, 54(2), 93. http://dx.doi.org/10.1037/0003-066X.54.2.93 